\title{
Physical and Chemical Properties of Long-term Salinized Soils
}

\author{
Anna Tedeschi ${ }^{1}$, Giovanna Angelino ${ }^{2}$, Celestino Ruggiero ${ }^{2 *}$ \\ ${ }^{1} \mathrm{CNR}-\mathrm{ISAFOM}$ \\ Via Patacca 85, 80056 Ercolano (Na), Italy \\ ${ }^{2}$ Dipartimento di Ingegneria Agraria e Agronomia del Territorio, Univerità di Napoli "Federico II" \\ Via Università 100, 80055 Portici (Na), Italy
}

Received: 26 Febrary 2005. Accepted: 10 March 2006

\begin{abstract}
In some areas, particularly in the Mediterranean regions, saline water is a source of water for crop irrigation. Consequently during the time, the use of this water may cause significant modifications of the soil physic-chemical properties and plant toxicity. The purpose of this investigation was to assess the variation of soil stability index and of ECe, ESP, pH, exchangeable potassium, bulk density, soil hydraulic conductivity and water retention curve (h( $\theta)$ ), for a clay sandy soil, which was irrigated over 12 years with saline water. The soil stability index was evaluated by 2 methods: after wetting the sample (Water Stability Index = WSI) and without the pre-wetting step (Water Stability Dry Index $=$ WSDI). The measures have been taken at three depths along the soil profile: $0-0.30,0.30-0.60$ and $0.60-0.90 \mathrm{~m}$. The saline water was obtained by adding commercial sea salt to the irrigation water with the result of a final concentrations of $0.25\left(2.5 \mathrm{~g} \mathrm{l}^{-1}\right), 0.5\left(5 \mathrm{~g} \mathrm{l}^{-1}\right)$ and $1 \%\left(10 \mathrm{~g} \mathrm{l}^{-1}\right)$. A non-salinized control was also included. The increasing salinity of the irrigation water increased at all the depths ECe, ESP and pH, while exchangeable potassium decreased. Assessment of soil aggregates stability without samples pre-wetting (WSDI) allowed us to better discriminate among the different samples examined. Aggregate stability for each of the soil layers decreased at increasing salinity of the irrigation water. Long term salinization affected the aggregate stability of the deepest layers. The soil hydraulic conductivity decreased also, while bulk density increased. The shape of the soil water retention curve was also affected by salinity. In the salinized plots less water is relaxed within $-150 \div-12$ $\mathrm{cm} \psi$ range. The available water was reduced at increasing salinity. Irrigation with saline water on clay-sandy soils increases ECe, $\mathrm{pH}$ and ESP, all of which negatively affect the soil aggregate stability. Damage to the soil structure remarkably reduces the available water and soil hydraulic conductivity. The magnitude of these deleterious effects may increase through the years and in proportion to salt concentration in the irrigation water.
\end{abstract}

Key-words: salinity, soil structure, physical properties, chemical properties.

\section{Introduction}

The use of saline water in irrigated agriculture may cause noxious salt accumulation in both the soil and the plant (Maas, 1986; Lauchli and Epstein, 1990).

The excess of sodium is most prejudicial in salinized soils since it may seriously damage the soil physical-chemical properties, but it may also hinder ion uptake, causing toxicity to the plant. In clayey soils, $\mathrm{Na}^{+}$ions with their hydration molecules are adsorbed onto colloidal particles and they cause clay swelling and disper- sion (Quirk and Shofield, 1955). These two events may lead to the clogging of the soil pores and, consequently, to a remarkable reduction of soil permeability and hydraulic conductivity properties (Rhoades and Ingvalson, 1969; Felhendler et al., 1974; Frenkel et al., 1978; Pupisky and Shainberg, 1979; Shainberg et al., 1981a,b; Shainberg and Levy, 1992).

Dispersion of clay particles and soil hydraulic conductivity properties are dependent on the degree of sodium saturation (Shainberg and Letey, 1981) and both of them affect the soil water retention curve $(h(\theta))$, by increasing

\footnotetext{
* Corresponding Author: Tel.: +39 081 2539124; Fax: +39 081 7755129. E-mail address: cruggier@unina.it
} 
the water content particularly in the $-1000 \leq \mathrm{h}$ $\geq-100 \mathrm{~cm}$ potential range (Somani, 1991).

In addition, the unstable soil structure associated with an excess of sodium may be further destabilised by the low resistance to the air entrapped in the soil aggregates, which may easily break when air is replaced by water (Varallyay, 1977; Henin, 1969).

Although there are several reports in the literature regarding the relationship between Exchangeable Sodium Percentage (ESP), electrical conductivity of saturated soil extract (ECe) and soil permeability to water, there are not many reports discussing the effects of water with high concentration of electrolytes, on soil structure, particularly in open field and using saline water over a long term.

Aim of this paper is to study, on a medium clayey soil, the effects of long term irrigation using water with different saline concentration on soil structure stability, soil water retention, hydraulic conductivity, and bulk density.

\section{Materials and methods}

The experiment was carried out in southern Italy (Sele plain, lat. $43^{\circ} 31^{\prime} \mathrm{N}$; long. $14^{\circ} 58^{\prime} \mathrm{E}$ ) on a deep clay-sandy soil (International textural classes), classified as Inceptisoil Haplustet type (USDA Soil taxonomy), with a high silt and low organic matter content, lime is practically absent (Table 1). The experimental field used for this study has been irrigated with saline water since 1988 . The experimental design included three saline irrigation treatments plus a non-salinized control $\left(\mathrm{EC}_{\mathrm{w}}=0.54 \mathrm{dS} \mathrm{m}{ }^{-1}\right)$. The saline water was obtained by adding commercial sea salt $\left(\mathrm{Na}^{+} 26,3 \%, \mathrm{Cl}^{-} 56.7 \%, \mathrm{~K}^{+} 16.4 \%\right.$, $\left.\mathrm{Ca}^{2+} 0.11 \%, \mathrm{Mg}^{2+} 0.11 \%, \mathrm{SO}_{4}{ }^{2-} 0.31 \%\right)$ to the irrigation water at the rate of $0.25\left(2.5 \mathrm{~g} \mathrm{l}^{-1}\right), 0.5$ $\left(5 \mathrm{~g}^{-1}\right)$ and $1 \%\left(10 \mathrm{~g}^{-1}\right)$, corresponding to $\mathrm{EC}_{\mathrm{w}}$ of $4.43 ; 8.46$ e $15.73 \mathrm{dS} \mathrm{m}^{-1}$. The irrigation treatments were arranged in a randomized block design replicated three times.

At the end of the1999 season and at the beginning of the 2000 season, on soil samples taken at 0-0.30, 0.30-0.60 and 0.60-0.90 m soil depth (identified as $0.15,0.45$ and $0.75 \mathrm{~m}$, respectively) was assessed the structure stability index (i.e. the 1-2 $\mathrm{mm}$ aggregates resistance to water breakdown). Measurements were performed on
Table 1. Soil physical and chemical characteristics of the experimental field. Average and Standard Error $(n=36)$.

\begin{tabular}{|c|c|c|c|c|}
\hline \multicolumn{3}{|c|}{ Texture fractions $\Phi$} & \multicolumn{2}{|c|}{ Values S.E. } \\
\hline \multirow[t]{5}{*}{ Sand } & $>0.0$ & & $42 \%$ & 0.58 \\
\hline & Silt & $0.02-0.002 \mathrm{~mm}$ & $27 \%$ & 0.35 \\
\hline & $\begin{array}{l}\text { Clay } \\
\text { Lime }\end{array}$ & $<0.002 \mathrm{~mm}$ & $\begin{array}{l}31 \% \\
\text { Traces }\end{array}$ & 0.43 \\
\hline & Orga & tter & $1.57 \%$ & 0.05 \\
\hline & Total & ogen & $0.0092 \%$ & 0.0003 \\
\hline
\end{tabular}

$10 \mathrm{~g}$ of soil, after wetting the sample according to the procedure of Malquori and Cecconi (1962) modified by Sequi (1973) (WSI = Water stability index). In addition, the structure stability index was assessed without the pre-wetting step (Tedeschi, 1999) (WSDI = Water stability dry index) which, in contrast, was required according to the WSI procedure. The WSI and WSDI methods to assess structure stability index were compared to verify which one was able to better highlight the potential NaCl-induced soil structure modifications. In 2000, only, exchangeable bases, cation-exchange capacity, electrical conductivity of the saturation extracts (ECe), and $\mathrm{pH}$ were also measured. In addition, for each soil depth $(0.15,0.45$ and 0.75 $\mathrm{m})$ water retention curve, soil saturated hydraulic conductivity and bulk density were assessed on undisturbed samples. The samples were drawn in a trench that was dig in the central part of field plot. For the three layers, on the lateral wall of trench, were drawn progressively two samples with cylinder of $0.15 \mathrm{~m}$ of diameter and 0.15 of depth. The samples were made through manual pressure on the cylinder, by removing progressively the soil around, that was used for other parameter analysis. Water retention curves were drawn using the Stakman apparatus (-200 $\leq \mathrm{h} \geq 0 \mathrm{~cm})$ and the Richards' chamber $(-12000$ $\leq \mathrm{h} \geq-200 \mathrm{~cm})$. Soil saturated hydraulic conductivity, $\mathrm{k}_{\mathrm{s}}$, was measured using the variable pressure head (Reynolds and Elrick, 2002).

Statistical analysis has been done as a splitsplit plot design with repeated measurement over space (depth) and, for structure stability indexes also over time (year), by a "Statistica" software package, with a multivariate approach (MANOVA). Comparison of the means was performed using the Student-Newman-Keuls (SNK) multiple range test at the $5 \%$ probability level. 


\section{Results}

\subsection{Structure Stability Index}

The structure stability index of 2000 compared to 1999 was statistically not different, so we report the average of the two years.

Figure 1 displays the interaction term method x salinity for the structure stability indexes (WSI and WSDI). A structure stability decrease was observed at increasing salinity of the irrigation water up to $0.5 \%$ treatment. Using the WSI method it was not possible to detect any significant difference between the $0.5 \%$ and $1.0 \%$ treatments, however, in contrast, using the WSDI the structure stability of the $1 \%$ treatment was significantly lower compared to the $0.5 \%$ treatment.

The salt-dependent structure stability decrease was not similar for each of the soil layers considered, as the interaction term depth $\mathrm{x}$ salinity shows (Figure 2). In non-salinized soils at $0.75 \mathrm{~m}$ the structure stability was higher compared with the other layers considered, while in salinized plots the structure stability at the different depths was almost the same.

\subsection{Chemical properties}

The electrical conductivity of the saturation extract (ECe) increased with the salt concentration of the irrigation water starting from $0.25 \%$, and mainly in the deeper layers ( 0.45 and 0.75 $\mathrm{m}$ ), which showed similar values (Figure 3 ), with

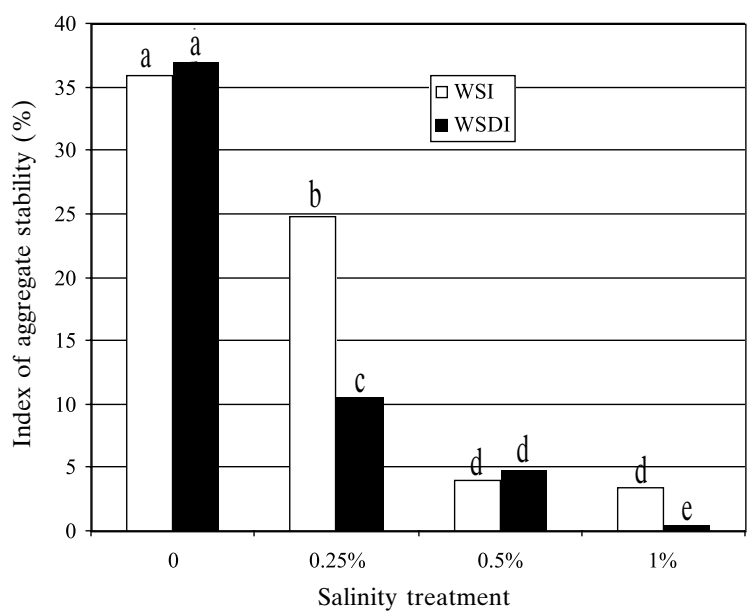

Figure 1. Structure stability index measured according to the WSI and WSDI methods for the four treatments under observation (method $\mathrm{x}$ salinity interaction). Values followed by the same letter are not significantly different at $\mathrm{P} \leq 0.05$ (SNK test).

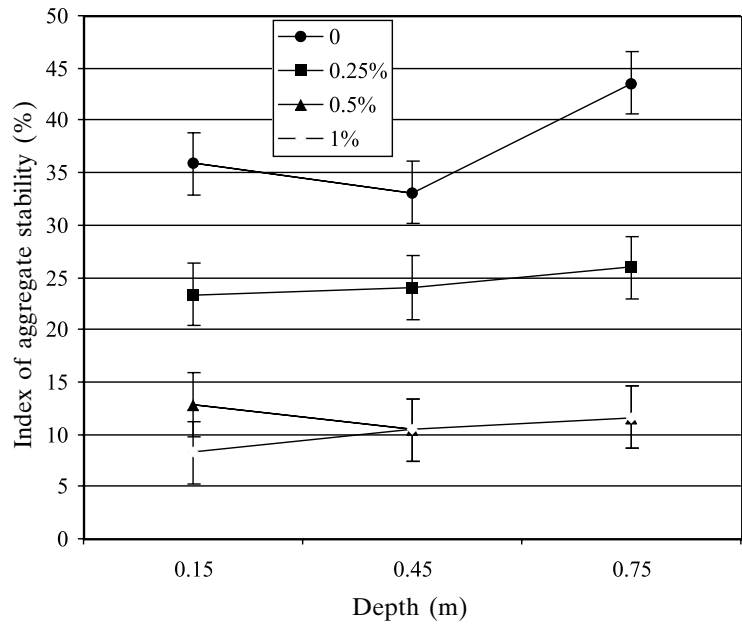

Figure 2. Structure stability index (average of WSI and WSDI and of 1999 and 2000 values) related to the four treatments and for the three depth (depth $\mathrm{x}$ salinity interaction). Vertical bars indicate confidence interval at $\mathrm{P} \leq 0.05$.

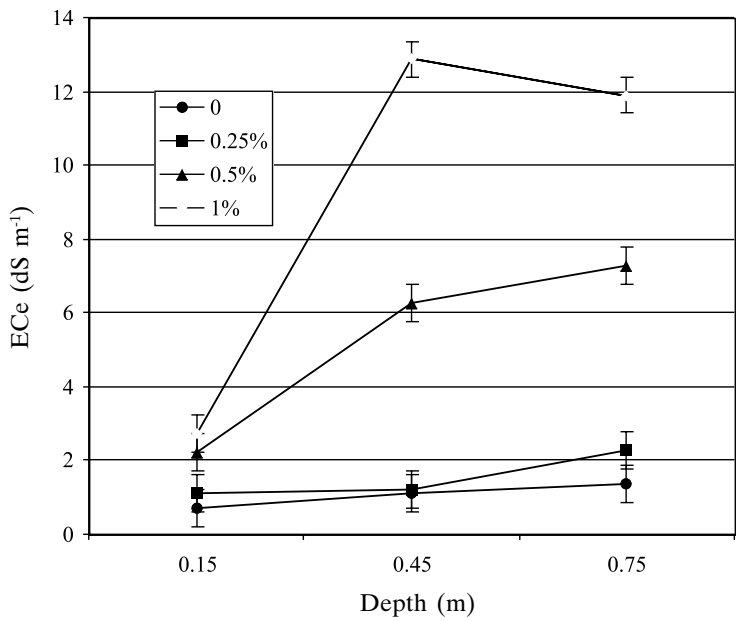

Figure 3. Electrical conductivity of the paste extract (ECe) against the three depths and the four treatments under observation (depth $\mathrm{x}$ salinity interaction). Vertical bars indicate confidence interval at $\mathrm{P} \leq 0.05$.

the exception of the $0.25 \%$ treatment for which the ECe at $0.75 \mathrm{~m}$ depth was higher compared to the other soil layers.

The interaction terms depth $\mathrm{x}$ salinity shows an exchangeable sodium percentage (ESP) increase at increasing salinity (Figure 4). The ESP values were similar at 0.45 and $0.75 \mathrm{~m}$ and for salinized plots were significantly higher compared with those measured at $0.15 \mathrm{~m}$. We did not observe any ESP variation along the soil profile of non-salinized control plots. 


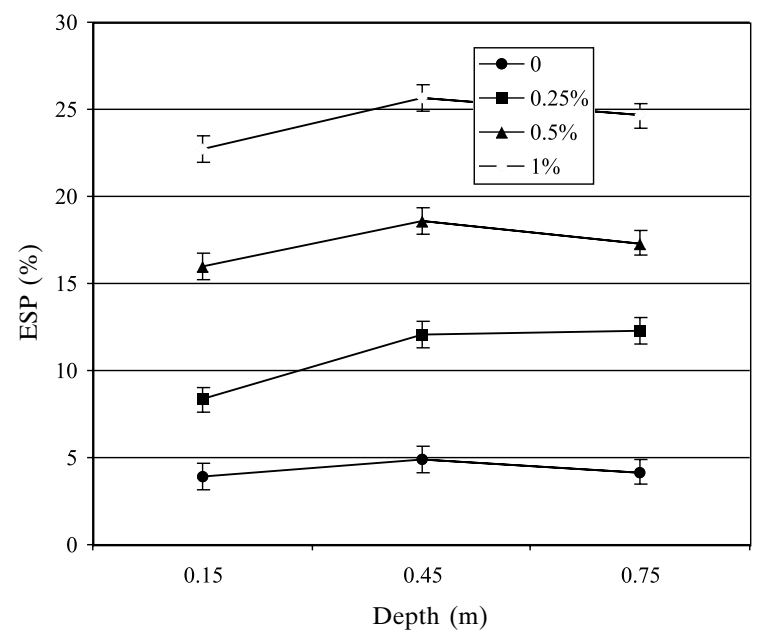

Figure 4. Exchangeable sodium percentage (ESP) against the three depths and the four treatments under observation (depth $\mathrm{x}$ salinity interaction). Vertical bars indicate confidence interval at $\mathrm{P} \leq 0.05$.

The exchangeable potassium (Figure 5) decreased at increasing salinity, although this response was detected mainly in the top $0.15 \mathrm{~m}$ soil layer. We did not find significant differences between the non salinized and $0.25 \%$ treatment plots and between the 0.5 and $1 \%$ plots for the deepest layers.

Water salinity affected the soil $\mathrm{pH}$ at each of the soil depths considered (Figure 6). Specifically, in the $0.15 \mathrm{~m}$ soil layer the $\mathrm{pH}$ increased with the increasing salinity, whereas at the deepest layers the $\mathrm{pH}$ did not increased for a salinity higher than $0.25 \%$.

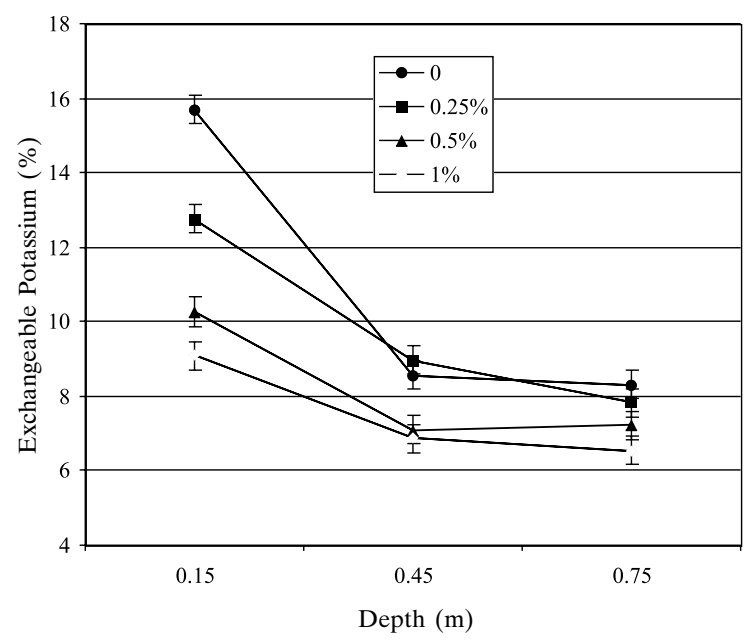

Figure 5. Exchangeable potassium for the three depths and the four treatments under observation (depth $\mathrm{x}$ salinity interaction). Vertical bars indicate confidence interval at $\mathrm{P} \leq$ 0.05 .

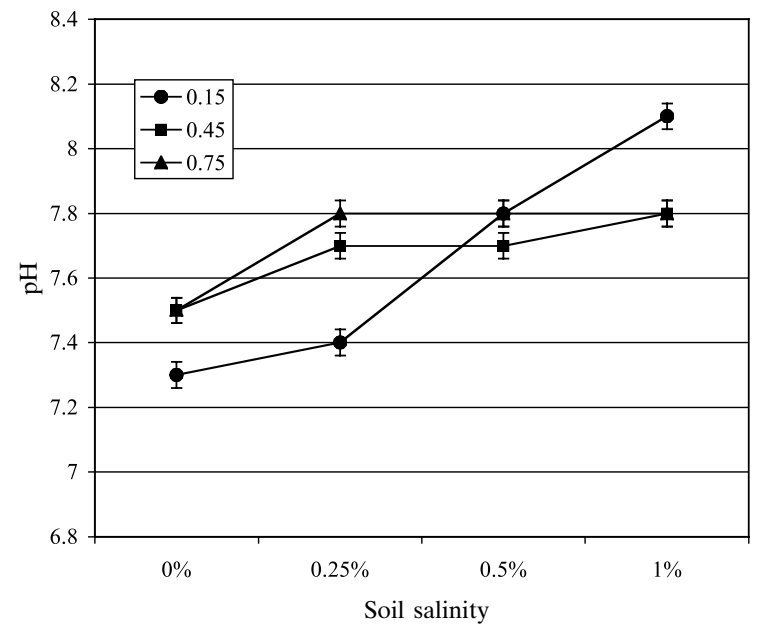

Figure 6. $\mathrm{pH}$ values in response to soil depth and salinization (depth $\mathrm{x}$ salinity interaction). Vertical bars indicate confidence interval at $\mathrm{P} \leq 0.05$.

\subsection{Physical properties}

Hydraulic conductivity values of saturated soil $\left(\mathrm{k}_{\mathrm{s}}\right)$ are reported in table 2 . Salinity reduced hydraulic conductivity (Figure 7). This was only moderately reduced in the $0.25 \%$ plot at the deepest layers, whose value was similar to that of the non-salinized control. A very high reduction was observed at the highest salinity levels $(0.5$ and $1 \%)$ in all layers, whereas for the $0.5 \%$ salinized plot in the 0.15 layer was lower.

The trend of the water retention curve was

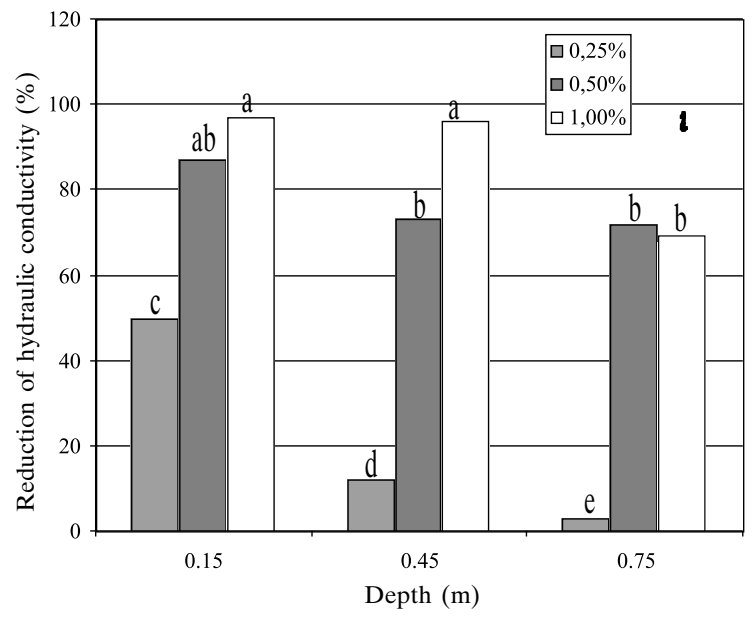

Figure 7. Reduction (Calculated with respect to the value of the non salinized plot at the same depth) of soil hydraulic conductivity in response to soil depth and salinization (depth $\mathrm{x}$ salinity interaction). Values followed by the same letter are not significantly different at $\mathrm{P} \leq 0.05$ to the SNK test. 
Table 2. Soil hydraulic conductivity (Ks) in response to salinity treatments and soil depth. Values followed by the same letter are not significantly different at $\mathrm{P} \leq 0.05$ to the Student-Newman-Keuls test.

Salt concentration $\quad \mathrm{Ks}(\mathrm{cm} \mathrm{min}-1)$ at depth of of the treatments

\begin{tabular}{lcccc}
\hline & $0.15 \mathrm{~m}$ & $0.45 \mathrm{~m}$ & $0.75 \mathrm{~m}$ & Average \\
\hline $0 \%$ & 7.15 & 0.233 & 0.126 & $2.50 \mathrm{a}$ \\
$0.25 \%$ & 3.58 & 0.205 & 0.122 & $1.30 \mathrm{~b}$ \\
$0.5 \%$ & 0.92 & 0.062 & 0.035 & $0.34 \mathrm{c}$ \\
$1 \%$ & 0.22 & 0.010 & 0.011 & $0.14 \mathrm{~d}$ \\
Average & $2.971 \mathrm{a}$ & $0.168 \mathrm{~b}$ & $0.074 \mathrm{c}$ & \\
\hline
\end{tabular}

the same for the three soil layers examined, so we report the average. The water content of salinized plots was higher compared to the non-salinized control in the tensiometric $\Psi$ range of $-12000 \div-12 \Psi \mathrm{cm}$, as described by the curves reported in figure 8 and indicates by the cluster analysis (Figure 9). Differences were higher within a $-150 \div-12 \mathrm{~cm} \Psi$ range. In regard to the salinity level, the $1 \%$ treatment in the $\Psi$ range $-12000 \div-3000 \mathrm{~cm}$ had higher water content compared to 0.25 and $0.5 \%$, which were significantly different from each other only at $\Psi=-12000 \mathrm{~cm}$. Therefore, the available water, calculated on the integral of the curves, decreased in the salinized plots.

The bulk density increased with the salinity increasing, but mainly in the top $0.15 \mathrm{~m}$. However, this effect was smaller in the deeper layers (Figure 10).

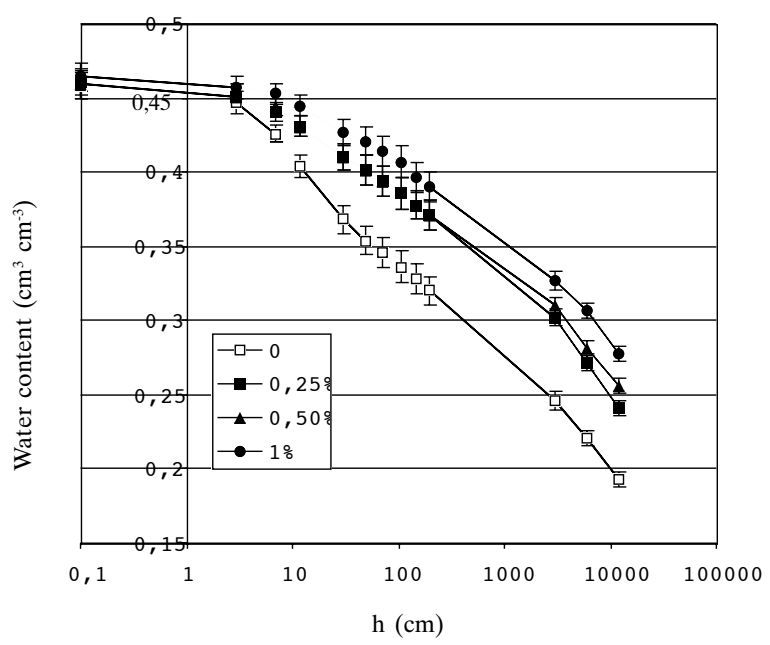

Figure 8. Water retention curves in response to salinity treatments (tension $x$ salinity interaction). Mean values of three depths. Vertical bars indicate confidence interval at $\mathrm{P} \leq 0.05$.

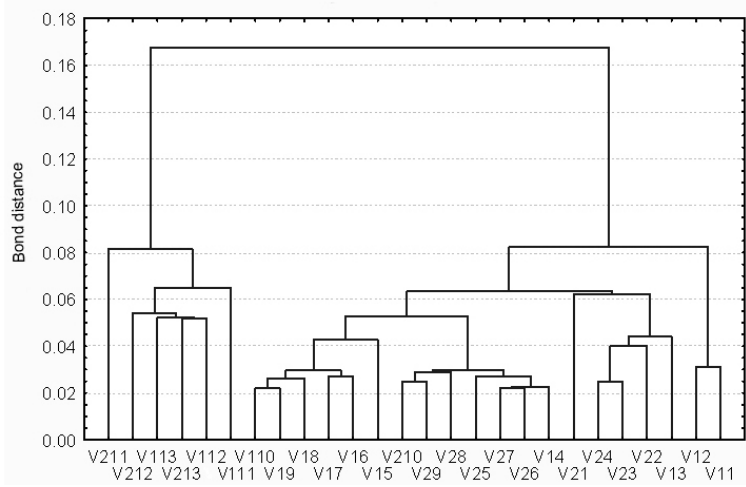

Figure 9. Dendrogramm of the soil water content at the different tensiometric $-12000 \div-0.1 \mathrm{~cm} \Psi$ range for the nonsalinized (V1i) and the average of salinized plots (V2i), for $\mathrm{i}=1 \ldots 13$ (tension). Single bond, euclidean distance

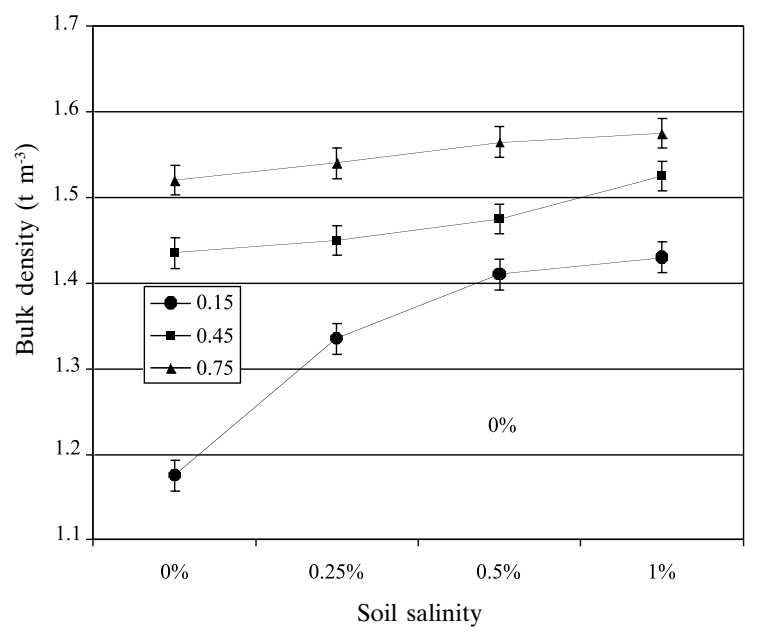

Figure 10 . Bulk density values in response to salinity treatments and soil depths (depth $\mathrm{x}$ salinity interaction). Vertical bars indicate confidence interval at $\mathrm{P} \leq 0.05$.

\section{Discussion}

Assessment of soil aggregates stability without samples pre-wetting (WSDI) allowed us to better discriminate the different samples examined. These soils all are rather rich in illite, which is typical of the Sele plain soils (Salerno - Italy) (Barbieri et al., 1976; Postiglione et al., 1995). The WSDI procedure was also effective for vermiculite-montmorillonite soil (with trace of illite) from the Volturno plain (Caserta - Italy) as reported by Tedeschi (1999).

Aggregate stability for each of the soil layers examined decreased at increasing salinity of the irrigation water. Long-term salinization af- 
fected the aggregate stability also in the deepest soil layers, for which Postiglione et al. (1995), in an earlier study performed on the same soil, did not reported any detrimental effect of salinization. This finding could be associated to the effect of the winter rainfall that, during the years, may have caused ion (mainly $\mathrm{Na}^{+}$) leaching into deeper soil layers. This result is consistent with the ESP values that we measured at $0.75 \mathrm{~m}$ depth (Figure 5). Aggregate stability has been negatively correlated with ESP $\left(\mathrm{Y}=74.8 \mathrm{X}^{-1.2} ; \mathrm{R}^{2}=\right.$ $0.95^{* *}, \mathrm{R}^{2}$ (corr.) $=0.87^{* *}$ ). At the $0.75 \mathrm{~m}$ depth, the non-salinized control had the highest stability index (44\%), which indirectly confirmed the soundness of this relationship. Interestingly, a mild but significant decreased soil structure stability was observed in the 0.15 and $0.45 \mathrm{~m}$ soil layer of non-salinized control plots, which was possibly associated to a mechanical damage to the soil structure caused by cultural practices. It was quite difficult to uncouple mechanical vs. chemical damage in salinized plots, where both phenomena are likely to co-exist.

As a consequence of decreased soil structure stability, the soil hydraulic conductivity also decreased. A lowest hydraulic conductivity was found at the highest salt concentration. The opposite relationship between high ESP values and low hydraulic conductivity has been reported in the literature (Quirk and Shofield, 1955; Gardner et al., 1960). Hydraulic conductivity is associated with the level of soil bulk density, and consequently, with the soil depth (Table 2). However, at the same soil depth of different salinization treatments, the hydraulic conductivity decreased with increasing soil salinity. A similar response was observed for the bulk density (Figure 9).

The shape of the soil water retention curve was also affected by salinity. In the salinized plot less water is relaxed within a -150 and $-12 \mathrm{~cm}$ $\Psi$ range, which is in the range of the macro and meso porosity (Figure 8). More water is held in the last part of the curve in the salinized plots. As a consequence in this plots the available water was reduced.

It has been demonstrated that an excess of $\mathrm{Na}^{+}$in the nutrient solution hinders the acquisition of $\mathrm{K}^{+}$, which consequently may cause nutritional imbalance. The exchangeable $\mathrm{K}^{+}$was reduced at increasing salinity (Figure 5). However the $\mathrm{Na}^{+} / \mathrm{K}^{+}$competition effect was found mainly in the topsoil where the concentration of $\mathrm{K}^{+}$is usually higher compared to deeper soil layers.

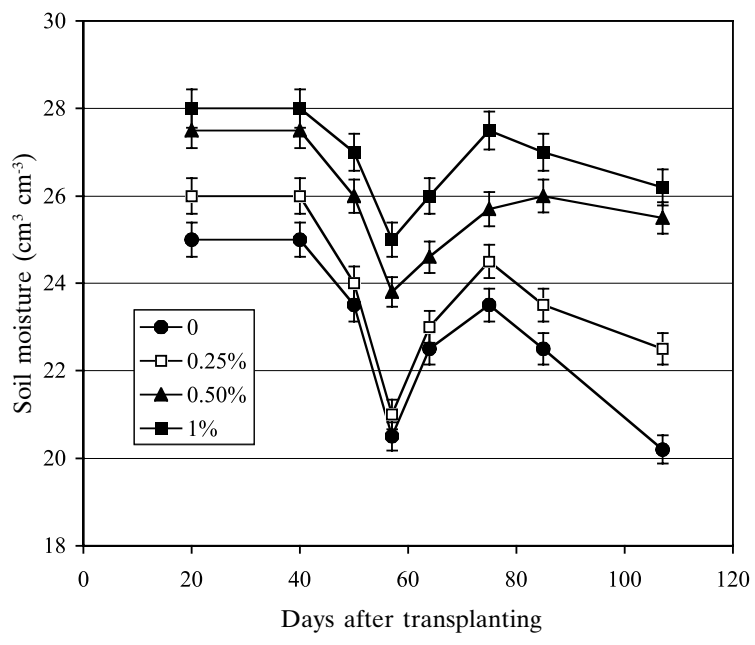

Figure 11. Soil moisture vs. time in response to soil depth and salinity treatments (time $\mathrm{x}$ salinity interaction). Values are means of 3 depths and 3 replications Measurements were taken before irrigation. Vertical bars indicate confidence interval at $\mathrm{P} \leq 0.05$.

The $\mathrm{pH}$ increased in salinized soils. Variations in soil $\mathrm{pH}$ may affect other processes, including ion mobility and uptake as well as microbial activity (Läuchli end Epstein, 1990). Throughout the tomato growth season (1999) the soil water content increased with increasing soil salinization (Figure 11). This may be likely due both to a decreased plant water uptake and a reduced soil hydraulic conductivity. Increasing salinity also inhibited root development (Figure 12).

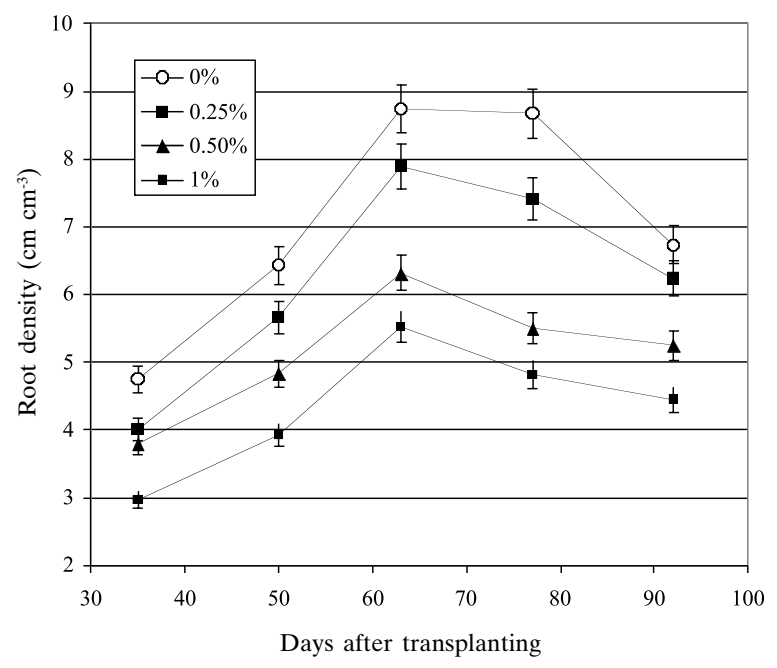

Figure 12 . Root density vs. time in response to salinity treatments (time $\mathrm{x}$ salinity interaction). Values are means of 3 depths and 3 replications. Vertical bars indicate confidence interval at $\mathrm{P} \leq 0.05$. 
The reduced root development may have been a consequence of reduced photosyntates availability associated with leaf growth inhibition. Alternatively, a disrupted soil structure may have caused anoxia and mechanical impediment, both of which may directly inhibit a normal root development.

We may conclude that irrigation with saline water on clay-sandy soils increases $\mathrm{ECe}, \mathrm{pH}$ and ESP, all of which negatively affect the soil aggregate stability. Damage to the soil structure remarkably reduced the available water and soil hydraulic conductivity. The magnitude of these deleterious effects may increase through the years and in proportion to the salt concentration in the irrigation water.

\section{Acknowledgements}

The authors would like to thank P. Di Fiore for the hydraulic measurements and M. Soprano and G. Castiello for the chemical analyses.

\section{References}

Barbieri G., Ruggiero C., Zerbi G. 1976. Capacità idrica di campo: variabilità in funzione dell'epoca e delle modalità di rilievo in due ambienti. Riv. di Agronomia, 4:261-267.

Felhendler R., Shainberg I., Frenkel H. 1974. Dispersion and hydraulic conductivity of soils in mixed solution. Trans. of the $10^{\text {th }}$ Inter. Cong. of Soil Sci. (Moscow) I, 103-112. Moscow: Nauka Pub. House.

Frenkel H., Goertzen J.O., Rhoades J.D. 1978. Effects of clay type content, exchangeable sodium percentage, and electrolyte concentration on clay dispersion and soil hydraulic conductivity. Soi Sci. Soc. Am. J., 42:3239.

Gardner W.R., Mayhugh M.S., Hoerzten J.O., Bower C.A. 1960. Effect of elettrolyte concentration and exchangeble sodium percentage on diffusivity of water in soil. Soil Sci., 88:270-274.

Henin S., Gras R., Monnier G. 1969. La stabilité structurale. In: Masson et $\mathrm{C}^{\text {ie }}$ (eds.): Le profil cultural, 109142. Paris.

Läuchli A., Epstein E. 1990. Plant response to saline and sodic conditions. In: Tanij K.K. (ed.): Agricultural salinity assessment and management. ASCE Manuals and Reports on Engineering Practice, 71, 113-137.
Maas E.V. 1986. Salt tollerance of plants, Applied Agr. Res., 1:12-26.

Malquori A., Cecconi S. 1962. Determinazione seriale dell'indice di struttura del terreno. Agrochimica, 6:198-204.

Pupisky H., Shainberg I. 1979. Salt effects on the hydraulic conductivity of a sandy soil. Soil Sci. Soc. Am. J., 43:429-433.

Postiglione L., Barbieri G., Tedeschi A. 1995. Long-term effects of irrigation with saline water on some characteristics of a clay loam soil. Riv. di Agron., 29:2430.

Quirk P.J., Shofield R.K. 1955. The effect of electrolyte concentration on soil permeability. J. Soil Sci., 6:163178.

Rhoades J.D., Ingvalson R.D. 1969. Macroscopic swelling and hydraulic conductivity properties of four vermiculite soils. Soil Sci. Soc. Am. J., 33:364-369.

Sequi P., Guidi G., Petruzzelli G. 1973. Sulla determinazione dell'efficacia dei condizionatori sulla struttura del suolo, Agrochimica, 1-2:150-155.

Shainberg I., Rhoades J.D., Prather R.J. 1981a. Effect of low electrolyte concentration on clay dispersion and hydraulic conductivity of a sodic soil. Soil Soc. Sci. Am. J., 45:273-277.

Shainberg I., Rhoades J.D., Prather R.J. 1981b. Effect of mineral weathering on clay dispersion and hydraulic conductivity of sodic soils. Soil Soc. Sci. Am. J., 45:287-291.

Shainberg I., Letey J. 1983. Response of soils to sodic and saline conditions. Hilgardia, 52, 1-57.

Shainberg I., Levy G.J. 1992. Physical-chemical effects of salts upon infiltration and water movement in soils. In: Wagenet R.J., Baveye P., Stewart B.A. (eds.): Interacting processes in soil science, 38-93.

Somani L.L. 1991. Crop production with saline water. In: Crop Production with saline water, 1-308. Agro Botanical Publishers, India.

Tedeschi A. 1999. Influence of soil sample conditioning in the evaluation of soil structure stability as affected by irrigation with saline water. Ital. J. Agron., 3:117-122.

Varallyay G. 1977a. Moisture states and flow phenomena in salt-affected soils. In: Proceedings of the IndoHung Seminar on management salt affected soils, 85102.

Varallyay G. 1977b. Soil water problems related to salinity and alkalinity in irrigated lands. In: Arid Land Irrigation in Developing Countries, 251-264. Pergamon press, Oxford. 